\title{
Correction: Acute subretinal abscess in Staphylococcus aureus septicaemia with endophthalmitis showcased by multimodal retinal imaging and with 2-year follow-up
}

Prajapati R, Newton P, Ahmad S, et al. Acute subretinal abscess in Staphylococcus aureus septicaemia with endophthalmitis showcased by multimodal retinal imaging and with 2 -year follow-up. BMJ Case Rep 2018;11:e227288. doi: 10.1136/bcr-2018-227288.

This article was previously published with an error. The corresponding author's name should be written with initial. Simon Kelly should be Simon P Kelly.

(C) BMJ Publishing Group Limited 2018. No commercial re-use. See rights and permissions. Published by BMJ.

BMJ Case Rep 2018;11:e227288corr1. doi:10.1136/bcr-2018-227288corr1

D Check for updates

Copyright 2018 BMJ Publishing Group. All rights reserved. For permission to reuse any of this content visit https://www.bmj.com/company/products-services/rights-and-licensing/permissions/

BMJ Case Report Fellows may re-use this article for personal use and teaching without any further permission.

Become a Fellow of BMJ Case Reports today and you can:

- Submit as many cases as you like

- Enjoy fast sympathetic peer review and rapid publication of accepted articles

- Access all the published articles

- Re-use any of the published material for personal use and teaching without further permission

For information on Institutional Fellowships contact consortiasales@bmjgroup.com

Visit casereports.bmj.com for more articles like this and to become a Fellow 